\title{
Faktor-Faktor Yang Mempengaruhi Rendahnya Pengguna Metode Kontrasepsi Jangka Panjang (MKJP) Di Kecamatan Batauga Kabupaten Buton Selatan
}

\author{
La Hamiru Ane ${ }^{1}$ \\ 1Penyuluh BKKBN Sulawesi Tenggara \\ Email:lahamiruane@gmail.com
}

\begin{abstract}
Abstrak, Penelitian ini bertujuan untuk mengetahui faktor-faktor yang mempengaruhi rendahnya pengguna Metode Kontrasepsi Jangka Panjang (MKJP) di Kecamatan Batauga Kabupaten Buton Selatan. Penelitian yang digunakan adalah penelitian Deskriptif Kualitatif, data yang ditemukan dari hasil wawancara dan pengamatan tersebut akan dianalisis secara Kualitatif dibantu dengan penggunaan Microsoft Excell 2010. Hasil penelitian ini menjelaskan bahwa bahwa masyarakat kurang teredukasi perihal manfaat dan tata cara penggunaanya, disisi lain faktor budaya juga turut mendukung respon negatif masyarakat tersebut. Sedangkan faktor-faktor yang secara langsung memengaruhi penggunaan MKJP di Kecamatan Batauga diataranya adalah kurangnya pengetahuan tentang MKJP, Kurangnya Komunikasi-Informasi dan Edukasi terkait MKJP kepada masyarakat, mahalnya biaya penggunaan MKJP ditengah ekonomi masyarakat kecamatan batauga yang tergolong rendah, dan kurangnya dukungan pria/ suami dalam penggunaan MKJP.
\end{abstract}

Kata Kunci : Kontrasepsi Jangka Panjang (MKJP), Alat Kontrasepsi

Abstract: This study aims to determine the factors that influence the low users of the Long-Term Contraception Method (MKJP) in Batauga District, South Buton Regency. The research used is descriptive qualitative research, data found from the results of interviews and observations will be analyzed qualitatively with the help of using Microsoft Excel 2010. The results of this study explain that the public is less educated about the benefits and procedures for its use, on the other hand cultural factors also participate. support the negative response of the community. Meanwhile, the factors that directly influence the use of MKJP in Batauga District include the lack of knowledge about MKJP, Lack of Communication-Information and Education related to MKJP to the community, the high costs of using MKJP in the middle of the low economic community in Batauga sub-district, and the lack of support from men/ husbands. in the use of MKJP.

Keywords: Long Term Contraception (MKJP), Contraception 


\section{Pendahuluan}

Indonesia merupakan negara berkembang yang menempati urutan keempat dengan jumlah penduduk terbesar di dunia setelah Cina, India, dan Amerika Serikat (Indikator Kesejahteraan Rakyat Tahun 2015). Berdasarkan Sensus Penduduk (SP) tahun 2010, jumlah penduduk Indonesia pada tahun 2010 sebanyak 237.641.326 jiwa, yang mencakup mereka yang bertempat tinggal di daerah perkotaan 118.320.256 jiwa $(49,79 \%)$ dan di daerah perdesaan 119.321.070 jiwa $(50,21 \%)$.

Angka kelahiran merupakan ukuran yang menunjukkan pertumbuhan penduduk di suatu negara. Di tingkat ASEAN, pada tahun 2013 rata-rata angka kelahiran sebesar 2,4 per 1.000 wanita usia subur. Laos merupakan negara dengan angka kelahiran tertinggi sebesar 3,2 per 1000 wanita usia subur, sedangkan Singapura mempunyai angka kelahiran terendah di tingkat ASEAN sebesar 1,3 per 1.000 wanita usia subur (Kemenkes, 2014)

Penggunaan kontrasepsi berkaitan dengan kesehatan reproduksi dimana komponen kesehatan reproduksi merupakan bagian dari kesehatan ibu. Program KB berperan besar untuk mencapai pengurangan kematian ibu melalui perencanaan keluarga dengan mengatur kehamilan yang aman, sehat dan diinginkan. Kehamilan yang tidak ideal (terlalu banyak, terlalu muda, terlalu tua, dan terlalu dekat jarak kelahiran) akan sangat membahayakan bagi kesehatan ibu (Kemenkes, 2014).

Indonesia, metode kontrasepsi yang digunakan akseptor KB didominasi oleh metode kontrasepsi jangka pendek yaitu suntikan dan pil KB dengan prevalensi berturut-turut $36 \%$ dan $15,1 \%$. Padahal metode kontrasepsi suntikan dan pil selain merupakan metode kontrasepsi yang paling banyak digunakan, juga penyumbang angka drop out (Non Kontrasespsi) paling banyak. Drop out rate (Non kontrasepsi) kontrasepsi suntik pada tahun 2003 sebesar 18,4\% dan meningkat menjadi 23 pada tahun 2007. Sedangkan drop out rate kontrasepsi pil pada tahun 2003 sebesar 31,9\% dan meningkat menjadi 38,8\% pada tahun 2007 (Kemenkes, 2014).

Metode Kontrasepsi Jangka Panjang (MKJP) merupakan kontrasepsi yang sangat efektif, mencakup durasi yang panjang dan bekerja hingga 10 tahun. Banyak sekali jenis alat kontrasepsi modern yang dapat digunakan baik alat kontrasepsi jangka pendek (Non MKJP) suntik, pil dan kondom ataupun menggunakan alat kontrasepsi jangka panjang (MKJP) IUD, MOW, MOP, dan implant. Mengingat tingginya angka drop out pada Metode Kontrasepsi Jangka Pendek (non MKJP) maka pengguna KB aktif diarahkan untuk meningkatkan cakupan Metode Kontrasepsi Jangka Panjang (selanjutnya akan disingkat MKJP). Hal ini dikarenakan, MKJP lebih efektif dalam mencegah kehamilan tidak diinginkan dari pada non MKJP (Winner dkk, 2012).

Penggunaan MKJP di Indonesia jauh dari target $(26,7 \%)$ dan menurun tiap tahunnya dari 13,7\% pada tahun 1991 sampai 10,6\% pada tahun 2012 (Kemenkes, 2014). Pada tahun 2013 
berdasarkan survei mini Badan Kependudukan dan Keluarga Berencana (BKKBN), cakupan MKJP di Indonesia hanya sebesar $12,4 \%$ dengan persentase berdasarkan jenis metode yaitu susuk (implan) KB (5,2\%), AKDR (Alat Kontrasepsi Dalam Rahim)/Intrauterine Device (IUD) (4,7\%), dan Metode Operasi Wanita (MOW) $(2,2 \%)$, padahal target MKJP yang diharapkan dapat dicapai adalah $26,7 \%$.

Hasil prevalensi KB di Sulawesi Tenggara berdasarkan Survei Pemantauan Pasangan Usia Subur tahun 2014 mencapai angka 65,4\% dengan metode $\mathrm{KB}$ yang didominasi oleh peserta KB suntikan (36\%), pil KB (15,1\%), Implant (5,2\%), IUD (4,7\%), dan MOW (2,2\%). Hasil tersebut sedikit menurun jika dibandingkan dengan hasil survei tahun 2015 prevalensi KB cenderung tetap pada kisaran angka 67,5\% (BKKBN, 2015).

Ketidakberhasilan kontrasepsi yang digunakan oleh pasangan usia subur yang ingin menunda, menjarangkan, atau menghentikan kelahiran dapat menyebabkan terjadinya kehamilan yang tidak diinginkan. Kontrasepsi yang sering menyebabkan kegagalan adalah kontrasepsi jangka pendek. Risiko kegagalan kontrasepsi jangka pendek (pil atau kondom) sebesar 4,55 per 100 partisipan per tahun. Dampak yang lebih serius dapat terjadi jika kehamilan terjadi pada ibu dengan usia diatas 35 tahun atau kurang dari 19 tahun, anak lebih dari 3, dan jarak kelahiran yang terlalu dekat dapat mengalami kehamilan risiko tinggi yang dapat menyebabkan kematian ibu (Kemenkes, 2014).
Penggunaan MKJP sangat dipengaruhi oleh faktor individu, karena keputusan akan menggunakan atau tidaknya jenis kontrasepsi tetap berada pada level individu. Faktor kognitif seperti pengetahuan, sikap, diskusi dengan pasangan tentang penggunaan MKJP. Penelitian Meskele dan Mekonnen (2014) memperoleh hasil wanita yang memiliki sikap positif atau setuju menggunakan MKJP dibandingkan dengan wanita yang memiliki sikap tidak setuju menggunakan MKJP. Faktor reproduksi seperti jumlah anak hidup, riwayat aborsi, umur pertama melahirkan, wanita yang memiliki lebih dari 4 anak berpeluang 5,8 kali dibandingkan dengan wanita yang tidak memiliki anak. Faktor sosiodemografi dan sosioekonomi seperti umur, tingkat pendidikan, tingkat penghasilan, status pekerjaan. Faktor eksternal diluar inidividu juga dapat berpengaruh terhadap penggunaan MKJP seperti tempat pelayanan KB (Greenberg dkk, 2013 : 14).

Berdasarkan hasil Survei Sosial dan Ekonomi Nasional (Susenas) 2015, Contraceptive Prevalence Rate (CPR) Nasional tahun 2015 menunjukkan sebagian besar Pasangan Usia Subur (PUS) peserta KB masih mengandalkan kontrasepsi suntikan 59,57\% dan pil 20,71\% dari total pengguna KB. Sedangkan persentase pengguna kontrasepsi jangka panjang (MKJP) terbesar adalah pengguna IUD 7,30\% dan susuk KB 6,21\%. Adapun peserta KB pria yang ada hanya mencapai sekitar $1,27 \%(\mathrm{MOP}=0,27 \%$ dan kondom $=1 \%)$. Kegiatan KB masih kurang dalam penggunaan Metode Kontrasepsi Jangka Panjang (MKJP) (BPS, 2016 : 70). 
Penggunaan Kontrasepsi di Kota Baubau Pada tahun 2019 peserta KB aktif adalah 15.076 orang atau $54,5 \%$. Jenis alat kontasepsi yang paling banyak digunakan oleh peserta KB aktif Non MKJP yaitu : Suntikan 5.990 orang (39,7\%), Pil KB 4.672 orang (31\%), Kondom 1392 orang atau (9,2\%) sedangkan peserta KB aktif MKJP yaitu : Implant 969 (6,4\%) dan, IUD 221 orang $(1,5 \%)$, MOP 19 orang $(0,1 \%)$, MOW 131 orang $(0,9 \%)$ (Profil BKKBN Kota Baubau Tahun 2018).

Jumlah pasangan usia subur (PUS) Kelurahan Labalawa Kec.Betoambari Kota Baubau yaitu 167 orang dan yang menggunakan kontrasepsi berjumlah 140 orang. Jenis alat kontrasepsi yang digunakan oleh peserta KB aktif Non MKJP yaitu : Suntikan 48 orang (34,3\%), Pil KB 72 orang $(51,4 \%)$, Kondom - sedangkan peserta KB aktif MKJP yaitu : Implant 16 (11,4\%) dan, IUD -, MOP-, MOW 4 orang (2,9\%) (Profil BKKBN Kota Baubau Tahun 2018). Penelitian ini bertujuan untuk mendeskripsikan sejumlah faktor yang turut memengaruhi fenomena yang tergambarkan diatas, sebagai bentuk data dan realitas yang terjadi dalam pengimplementasian MKJP di Kecamatan Batauga.

Kenyataanya rendahnya penggunaan MKJP di Kecamatan Batauga disebabkan adanya beberapa hambatan yang ditemu antara lain belum adanya petugas yang cukup untuk melaksanakan kotap, kurangnya saran dan prasarana yang mendukung, adanya pengaruh budaya yang menyebabkan masyarakat menolak memasang IUD karena malu dan larangan dari suami, serta masih rendahnya partisipasi pria ber-KB khusus MOP karena masih banyak suami yang takut untuk ikut MOP.

Merujuk pada penelitian Nikmawati (2017) mengungkap bahwa pemakaian MKJP dianggap belum efektif teredukasi di masyarakat, hal ini disebabkan oleh adanya ketakutan masyarakat untuk melakukan operasi, malu karena harus membuka organ intim, serta takut akan efek samping atau akibat pemasangan alat kontrasepsi MKJP. Masih pada penelitian yang sama, dinyatakan bahwa pandangan seperti tersebut diatas disebabkan oleh budaya setempat dan tingkat pendidikan terhadap MKJP masyarakat yang masih rendah. Mencermati kondisi diatas, maka penelitian ini difokuskan untuk mengkaji sejumlah variabel yang memungkinkan menjadi penghambat pelaksanaan MKJP di Kecamatan Batauga.

\section{Metode Penelitian}

Jenis penelitian ini adalah penelitian explanatory research yang menjelaskan hubungan antara variabel bebas dan variabel terikat melalui pengujian hipotesis serta menggunakan pendekatan cross sectional (Soekidjo Notoatmodjo, 2010). Populasi dalam penelitian ini adalah Pasangan Usia Subur (PUS) yang menggunakan KB kecamatan batauga yaitu sebanyak 140 orang. Pengambilan sampel dilakukan dengan menggunakan teknik simple random sampling, yaitu sebanyak 58 orang.

Instrumen yang digunakan dalam penelitian ini adalah kuesioner berisi: kuesioner A tentang karakteristik responden, B tentang pengetahuan seputar 
MKJP (19 pertanyaan), C tentang dukungan suami (4 pertanyaan), D tentang budaya (15 pertanyaan), dan E tentang Komunikasi, Informsi, dan Edukasi (KIE) KB (9 pertanyan). Analisis data dilakukan secara univariat dan bivariat menggunakan uji chi square $(\mathrm{a}=0,05)$.

\section{Hasil Penelitian dan Pembahasan}

\section{a. Profil Penggunaan MKJP Kecamatan Batauga}

Kecamatan Batauga adalah salah satu kecamatan yang ada di Kabupaten Buton Selatan dengan luas $75,83 \mathrm{~km}^{2}$ yang terdiri dari 4 Desa dan 8 Kelurahan yaitu Desa Lawela, Desa Lawela Selatan, Kelurahan Busoa, Kelurahan Bandar Batauga, Kelurahan Lakambau, Kelurahan Laompo, Kelurahan Molagina, Kelurahan Masiri, Kelurahan Majapahit, Desa Lampanairi, Kelurahan Bola, dan Desa Poogalampa.

Kecamatan Batauga merupakan salah satu perkampungan tua di Kabupaten Buton Selatan yang berusia ratusan tahun yang merupakan pemekaran dari Kabupaten Buton. Kecamatan Batauga Secara geografis terletak di antara 5,290 $5,59^{\circ}$ LS. memiliki luas pemukiman \pm 8 ha $/ \mathrm{m}^{2}$.

Kecamatan Batauga memiliki 290 Kepala Keluarga dengan jumlah jiwa 1100 orang yang terdiri dari laki-laki 578 orang dan perempuan 522 orang. Mayoritas Mata pencaharian sebagian besar penduduk adalah berprofesi sebagai petani organik dengan menerapkan cara bercocok tanam yang usianya ratusan tahun dan sebagai nelayan, pemecah batu dan tambang pasir. Mayoritas penduduk memiliki Pendidikan
Terakhir paling banyak hanya sampai Sekolah Dasar (SD).

Jumlah Pasangan Usia Subur (PUS) Kecamatan Batauga Kabupaten Buton Selatan yaitu 167 orang dan Pasangan Usia Subur (PUS) yang masih aktif sampai sekarang menggunakan kontrasepsi berjumlah 140 orang. Jenis alat kontrasepsi yang digunakan oleh peserta KB aktif Non MKJP yaitu : Suntikan 48 orang (34,3\%), Pil KB 72 orang $(51,4 \%)$, Kondom - sedangkan peserta KB aktif MKJP yaitu : Implant 16 (11,4\%) dan, IUD -, MOP-, MOW 4 orang $(2,9 \%)$.

Tabel 1.

Tabel Pencapaian Akseptor Aktif Kecamatan Batauga Kec Tahun 2018

\begin{tabular}{|c|c|c|c|}
\hline No & $\begin{array}{c}\text { Jenis } \\
\text { Kontrasepsi }\end{array}$ & Jumlah & $\begin{array}{c}\text { Persen } \\
(\%)\end{array}$ \\
\hline 1 & Suntikan & 48 & 34,3 \\
\hline 2 & Pil KB & 72 & 51,4 \\
\hline 3 & Kondom & 0 & 0 \\
\hline 4 & Implant & 16 & 11,4 \\
\hline 5 & IUD & 0 & 0 \\
\hline 6 & MOP & 0 & 0 \\
\hline 7 & MOW & 4 & 2,9 \\
\hline & Total & 140 & 100 \\
\hline
\end{tabular}

Sumber : BKKBN Kecamatan Batauga Tahun

2018

b. Faktor-Faktor penyebab rendahnya penggunaan Metode Kontrasepsi Jangka Panjang (MKJP).

Berdasarkan hasil penelitian menjelaskan bahwa faktor-faktor penyebab rendahnya penggunaan Metode Kontrasepsi Jangka Panjang (MKJP) yaitu : Kurangnya pengetahuan PUS mengenai MKJP, kurangnya informasi, komunikasi, dan edukasi KB, mahalnya biaya pelayanan KB 
MKJP dan kurangnya dukungan suami terhadap penggunaan MKJP, Hal ini dapat dilihat dari tabel di bawah ini:

Tabel 2.

Indikator Pengetahuan Responden Tentang MKJP

\begin{tabular}{|c|l|c|c|}
\hline No & $\begin{array}{l}\text { Tanggapan } \\
\text { Responden }\end{array}$ & Jumlah & Persentase \\
\hline 1. & Baik & 1 & 1,7 \\
2. & Cukup & 5 & 8,6 \\
3. & Baik & 52 & 89,7 \\
& Buruk & & \\
\hline & Jumlah & $\mathbf{5 8}$ & $\mathbf{1 0 0 \%}$ \\
\hline
\end{tabular}

Sumber : BKKBN Kecamatan Batauga Tahun

Berdasarkan tabel 2. Indikator Pengetahuan Responden Tentang MKJP, tanggapan baik (memiliki pengetahuan) sebanyak 1 orang (1,7\%), tanggapan cukup baik (cukup memiliki pengetahuan) sebanyak 5 orang $(8,6 \%)$ dan responden yang memiliki tanggapan buruk (tidak memiliki pengetahuan) sebanyak 52 orang $(89,7 \%)$.

Tabel 3.

Indikator Pengetahuan Responden Tentang MKJP Berdasarkan Jenis Kelamin

\begin{tabular}{|c|l|c|c|}
\hline No & $\begin{array}{c}\text { Tanggapan } \\
\text { Responden }\end{array}$ & Jumlah & Persentase \\
\hline 1. & Laki-Laki & 20 & 34,5 \\
2. & Perempuan & 38 & 65,5 \\
\hline & Jumlah & $\mathbf{5 8}$ & $\mathbf{1 0 0} \%$ \\
\hline
\end{tabular}

Sumber : BKKBN Kecamatan Batauga Tahun 2018

Berdasarkan tabel 3. Indikator Pengetahuan Responden Tentang MKJP Berdasarkan Jenis Kelamin, laki-laki sebanyak 20 orang (34,5\%), perempuan sebanyak 38 orang $(65,5 \%)$.
Tabel 4

Indikator Responden Tentang Komunikasi Tentang MKJP

\begin{tabular}{|c|l|c|c|}
\hline No & $\begin{array}{l}\text { Tanggapan } \\
\text { Responden }\end{array}$ & Jumlah & Persentase \\
\hline 1. & Baik & 1 & 1,7 \\
2. & Cukup & 5 & 8,6 \\
3. & Baik & 52 & 89,7 \\
& Buruk & \multicolumn{2}{|c|}{} \\
\hline \multicolumn{2}{|c|}{ Jumlah } & $\mathbf{1 0 0 \%}$ \\
\hline \multicolumn{2}{|c|}{ Sumber : BKKBN Kecamatan Batauga Tahun }
\end{tabular}

2018

Berdasarkan tabel 4. Indikator Komunikasi Tentang MKJP, tanggapan baik sebanyak 1 orang (1,7\%), tanggapan cukup baik sebanyak 5 orang $(8,6 \%)$ dan responden yang memiliki tanggapan buruk sebanyak 52 orang $(89,7 \%)$.

Tabel 5.

Indikator Responden Tentang Informasi Tentang MKJP

\begin{tabular}{|c|l|c|c|}
\hline No & $\begin{array}{l}\text { Tanggapan } \\
\text { Responden }\end{array}$ & Jumlah & Persentase \\
\hline 1. & Baik & 2 & 3,4 \\
2. & Cukup & 4 & 6,9 \\
3. & Baik & 52 & 89,7 \\
& Buruk & & \\
\hline & Jumlah & $\mathbf{5 8}$ & $\mathbf{1 0 0} \%$ \\
\hline
\end{tabular}

Sumber : BKKBN Kecamatan Batauga Tahun 2018

Berdasarkan tabel 5. Indikator Informasi Tentang MKJP, tanggapan baik sebanyak 2 orang $(3,4 \%)$, tanggapan cukup baik sebanyak 4 orang $(6,9 \%)$ dan responden yang memiliki tanggapan buruk sebanyak 52 orang $(89,7 \%)$. 
Tabel 6.

Indikator Responden Tentang Edukasi Tentang MKJP

\begin{tabular}{|c|l|c|c|}
\hline No & $\begin{array}{l}\text { Tanggapan } \\
\text { Responden }\end{array}$ & Jumlah & Persentase \\
\hline 1. & Baik & 1 & 1,7 \\
2. & Cukup & 7 & 12,0 \\
3. & Baik & 50 & 86,2 \\
& Buruk & & \\
\hline & Jumlah & $\mathbf{5 8}$ & $\mathbf{1 0 0} \%$ \\
\hline
\end{tabular}

Sumber : BKKBN Kecamatan Batauga Tahun

Berdasarkan tabel 7. Indikator Edukasi Tentang MKJP, tanggapan baik sebanyak 1 orang $(1,7 \%)$, tanggapan cukup baik sebanyak 7 orang $(12,0 \%)$ dan responden yang memiliki tanggapan buruk sebanyak 50 orang $(86,2 \%)$.

Tabel 7.

Indikator Responden Tentang Biaya Pelayanan KB MKJP

\begin{tabular}{|c|l|c|c|}
\hline No & $\begin{array}{l}\text { Tanggapan } \\
\text { Responden }\end{array}$ & Jumlah & Persentase \\
\hline 1. & Baik & - & - \\
2. & Cukup & - & - \\
3. & Baik & 58 & 100 \\
& Buruk & & \\
\hline & Jumlah & $\mathbf{5 8}$ & $\mathbf{1 0 0} \%$ \\
\hline
\end{tabular}

Sumber : BKKBN Kecamatan Batauga Tahun 2018

Berdasarkan tabel 7. Indikator Responden Tentang Biaya Pelayanan KB MKJP, responden yang memiliki tanggapan buruk sebanyak 58 orang $(100 \%)$.
Tabel 8.

Indikator Responden Tentang Dukungan Suami Terhadap Penggunaan MKJP

\begin{tabular}{|c|l|c|c|}
\hline No & $\begin{array}{l}\text { Tanggapan } \\
\text { Responden }\end{array}$ & Jumlah & Persentase \\
\hline 1. & Baik & 1 & 1,7 \\
2. & Cukup & - & - \\
3. & Baik & 57 & 98,3 \\
& Buruk & & \\
\hline \multicolumn{2}{|c|}{ Jumlah } & $\mathbf{5 8}$ & $\mathbf{1 0 0} \%$ \\
\hline \multicolumn{2}{|l|}{ Sumber: BKKBN Kecamatan Batauga Tahun 2018 }
\end{tabular}

Berdasarkan tabel 8. Indikator Responden Tentang Dukungan Suami Terhadap Penggunaan MKJP, tanggapan baik sebanyak 1 orang $(1,7 \%)$, tanggapan buruk sebanyak 57 orang $(98,3 \%)$.

Tabel 9.

Indikator Responden Tentang Dukungan

Suami Terhadap Penggunaan MKJP

Berdasarkan Tingkat Pendidikan

\begin{tabular}{|c|l|c|c|}
\hline No & $\begin{array}{l}\text { Tanggapan } \\
\text { Responden }\end{array}$ & Jumlah & Persentase \\
\hline 1. & SD & 30 & 51,7 \\
2. & SMP & 15 & 25,9 \\
3. & SMA & 13 & 22,4 \\
4. & DIII & - & \\
5. & D4 & - & \\
6. & S1 & - & \\
\hline \multicolumn{2}{|r|}{ Jumlah } & $\mathbf{5 8}$ & $\mathbf{1 0 0} \%$ \\
\hline
\end{tabular}

Berdasarkan tabel 9. Indikator Responden Tentang Dukungan Suami Terhadap Penggunaan MKJP Berdasarkan Tingkat Pendidikan, SD sebanyak 30 orang $(51,7 \%)$, SMP sebanyak 15 orang $(25,9 \%)$, SMA sebanyak 13 orang $(22,4 \%)$.

Berdasarkan hasil penelitian tersebut dapat dijelasakan bahwa metode Kontrasepsi Jangka Panjang (MKJP) 
merupakan kontrasepsi yang sangat efektif, mencakup durasi yang panjang dan bekerja hingga 10 tahun. Jenis-jenis alat kontrasepsi metode ini meliputi: Implant, Alat Kontrasepsi dalam Rahim (AKDR)/IUD (Intra Uterine Device), Metode Operasi Wanita (MOW)/Tubektomi, (MOP)/Vasektomi. Faktor-Faktor penyebab rendahnya penggunaan Metode Kontrasepsi Jangka Panjang (MKJP) yaitu:

\section{1) Kurangnya Pengetahuan Tentang MKJP}

Pengetahuan adalah terjangkaunya informasi (accessibility of information), adalah terkait dengan tindakan yang akan diambil oleh seseorang. Sebuah keluarga mau mengikuti program $\mathrm{KB}$, apabila keluarga ini memperoleh penjelasan yang lengkap tentang keluarga berencana : tujuan ber KB, bagaimana cara ber KB (alat-alat kontrasepsi yang tersedia), akibat-akibat sampingan ber KB dan sebagainya.

Berdasarkan keterangan yang didapat di lapangan sependapat bahwa pendidikan merupakan salah satu faktor yang sangat menentukan terhadap pengetahuan dan persepsi seseorang terhadap pentingnya keikutsertaan dalam KB. Seseorang yang berpendidikan tinggi umumnya memiliki pengetahuan terhadap sesuatu hal lebih luas, termasuk tentang pembatasan angka kelahiran. Hubungan antara pendidikan dengan pola pikir, persepsi dan perilaku masyarakat sangatlah signifikan dalam hal pengambilan keputusan pilihan-pilihan jenis KB. Selain faktor pendidikan, peran bidan tetaplah penting dalam menyosialisasikan jenis alat kontrasepsi kepada masyarakat. Kurangnya pemahaman masyarakat terhadap jenis-jenis kontrasepsi jangka panjang membuat program KB seakan berjalan di tempat (Shodiq, 2016).

Sejalan dengan itu, Suryanti (2019) mengungkapkan bahwa rendahnya penggunaan MKJP menunjukan hasil bahwa umur, jumlah anak dan pengetahuan merupakan faktor yang mempengaruhi rendahnya keikutsertaan penggunaan MKJP. Selain itu, pengetahuan responden pengguna non MKJP sebagian besar berpengetahuan kurang dibandingkan tingkat pengetahuan responden pengguna MKJP. Sedangkan dalam hasil wawancara kepada setiap responden di kecamatan batauga, menunjukkan tingkatpengetahuan terhadap MKJP sangat rendah bahkan pada beberapa individu baru mendengar istilah tersebut. Hal ini juga turut dipengaruhi oleh salah satu faktor rendahnya penggunaan Metode Kontrasepsi Jangka Panjang (MKJP) yaitu Kurangnya Pengetahuan PUS Mengenai MKJP dikarenakan banyaknya PUS yang berpendidikan Tamat SD saja. Tingkat pengetahuan sangat mempengaruhi seseorang dalam memilih jenis kontrasepsi yang akan digunakan.

\section{2) Kurangnya Komunikasi, Informasi, dan Edukasi KB}

Komunikasi, Informasi, dan Edukasi (KIE) Keluarga Berencana yang dilaksanakan oleh pihak kesehatan termasuk dalam pelaksanaan penyuluhan kesehatan pada umumnya. Dalam melaksanakan program KB, perlu diperhatikan bahwa bidang tanggung jawab kesehatan mencakup segi-segi pelayanan 
medis teknis dan pembinaan partisipasi masyarakat.

Dari hasil wawancara terhadap responden ditemukan bahwa salah satu faktor rendahnya penggunaan Metode Kontrasepsi Jangka Panjang (MKJP) yaitu Kurangnya komunikasi, informasi dan edukasi KB dikarenakan PUS bekerja di kebun sehingga tidak ada waktu untuk mengikuti pelatihan sosialisasi baik langsung dan tak langsung atau kunjungan rumah tentang $\mathrm{KB}$ efektif.

Hal ini sejalan dengan penelitian yang dilakukan oleh Hariyani (2013) tentang rendahnya keikutsertaan pengguna metode kontrasepsi jangka panjang pada pasangan usia subur memiliki hasil pengetahuan responden tentang kontrasepsi dikelompok PUS pengguna non MKJP rata rata lebih rendah bila dibandingkan dengan tingkat responden di kelompok PUS pengguna MKJP. Kondisi tersebut kemungkinan dikarenakan kurangnya informasi tentang kontrasepsi jangka panjang dari pada kelompok pengguna MKJP. Kurangnya pengetahuan tentang kontrasepsi jangka panjang pada kelompok PUS pengguna non MKJP dapat menunjukan bahwa variabel tersebut merupakan faktor yang mempengaruhi rendahnya keikutsertaan pengguna MKJP pada PUS (dalam Suryanti, 2019).

\section{3) Mahalnya Biaya Pelayanan MKJP}

Biaya sebagai faktor yang berpengaruh dalam pemilihan alat kontrasepsi. Harga obat atau alat kontrasepsi yang terjangkau menjadi faktor yang menentukan akseptabilitas cara kontrasepsi. Lebih lanjut dijelaskan bahwa kontrasepsi ideal harus memenuhi syarat-syarat tertentu, diantaranya adalah murah harganya sehingga dapat dijangkau oleh seluruh lapisan masyarakat.

Disisi lain, mahalnya biaya jasa pemasangan KB MJP berpengaruh terhadap rendahnya pemakaian alat kontrasepsi $\mathrm{KB}$ MKJP di masyarakat (Shodiq, 2016). Dari hasil wawancara terhadap sejumlah responden ditemukan bahwa salah satu faktor rendahnya penggunaan Metode Kontrasepsi Jangka Panjang (MKJP) yaitu mahalnya biaya pelayanan KB MKJP contohnya IUD, MOP dan MOW yang dilayani di fasilitas kesehatan.

\section{4) Kurangnya Dukungan Suami Terhadap Penggunaan MKJP \\ Di dalam Kamus Besar Bahasa} Indonesia, suami adalah pria yang menjadi pasangan hidup resmi seorang wanita (istri) yang telah menikah. Suami adalah pasangan hidup istri (ayah dari anak-anak), suami mempunyai suatu tanggung jawab penuh dalam suatu keluarga tersebut dan suami mempunyai peranan penting dimana suami sangat dituntut bukan hanya sebagai pencari nafkah akan tetapi suami sebagai motivator dalam berbagai kebijakan yang akan diputuskan termasuk merencanakan keluarga.

Dari hasil wawancara menjelaskan bahwa salah satu faktor rendahnya penggunaan Metode Kontrasepsi Jangka Panjang (MKJP) yaitu kurangnya dukungan suami terhadap penggunaan MKJP, hal ini dikarenakan ketidaknyamanan dalam penggunaan MKJP tersebut. 


\section{Kesimpulan}

Penggunaan MKJP menurut sebagian besar responden dalam penelitian ini setidaknya menjelaskan bahwa masyarakat kurang teredukasi perihal manfaat dan tata cara penggunaanya, disisi lain faktor budaya juga turut mendukung respon negatif masyarakat tersebut. Sedangkan faktor-faktor yang secara langsung memengaruhi penggunaan MKJP di Kecamatan Batauga diataranya adalah kurangnya pengetahuan tentang MKJP, Kurangnya Komunikasi-Informasi dan Edukasi terkait MKJP kepada masyarakat, mahalnya biaya penggunaan MKJP ditengah ekonomi masyarakat kecamata batauga yang tergolong rendah, dan kurangnya dukungan pria/ suami dalam penggunaan MKJP. Betapapun demikian, sejumlah faktor yang ditemukan ini sejatinya adalah faktor teknis sedang faktor yang bersifat kebijakan dan program seperti kesiapan dan kehandalan penyuluh lapangn juga memegang peranan penting, sedangkan dalam penelitian ini hal itu memang dianggap masih kurang optimal di lapangan.

\section{Daftar Pustaka}

Alfiah, Izmi Dzalfa. 2015. Faktor-faktor yang Berhubungan dengan Penggunaan Metode Kontrasepsi Jangka Panjang di Wilayah Kerja Puskesmas Kecamatan Kalideres Tahun 2015. Skripsi. Program Studi Kesehatan Masyarakat.Fakultas Kedokteran dan Ilmu Kesehatan.UIN Syarif Hidayatullah. Jakarta.

BKKBN. 2014. Pedoman Penyelenggaraan Pelayanan Keluarga Berencana Dalam Jaminan Kesehatan Nasional. BKKBN. Jakarta.
Christiani, C., Wahyuningsih, C. D., \& Martono, B. (2015). Faktor-faktor yang mempengaruhi pemakaian metode kontrasepsi jangka panjang (MKJP) provinsi Jawa Tengah. Serat Acitya, 3(2), 74

Dewi, P. H. C., \& Notobroto, H. B. (2015). Rendahnya Keikutsertaan Pengguna Metode Kontrasepsi Jangka Panjang Pada Pasangan Usia Subur. Biometrika dan Kependudukan, 3(1).

Hartanto, Hanafi. 2002. Keluarga Berencana dan Kontrasepsi. Pustaka Sinar: Jakarta

Indira. 2009. Faktor-faktor Pemilihan Kontrasepsi Pada keluarga Miskin. Universitas Diponegoro : Semarang.

Kartoyo, Azwini. 1981. Dasar-Dasar Demografi. Lembaga Demografi Fakultas Harapan : Jakarta.

Mantra. 2003. Pengantar Pendidikan (Penyuluhan) Kesehatan Masyarakat (Cetakan II). Universitas Diponegoro : Semarang

Mahmudah, L. T. N., \& Indrawati, F. (2015). Analisis faktor yang berhubungan dengan pemilihan metode kontrasepsi jangka panjang (MKJP) pada akseptor KB Wanita di Kecamatan Banyubiru Kabupaten Semarang. Unnes Journal of Public Health, 4(3).

Nikmawati, N. (2017). Faktor-Faktor yang Berhubungan dengan Penggunaan Metode Kontrasepsi Jangka Panjang. Jurnal Kebidanan, 6(12), 39-46.

Noor, Juliansyah, 2014. Metodologi Penelitian. Kencana : Jakarta.

Notoatmojo, Soekidjo. 2010. Pendidikan dan Perilaku Kesehatan. Rineka Cipta : Jakarta

Prawirodihardjo, Sarwono. 2002. Ilmu Kebidanan. Yayasan Bina Pustaka Sarwono Prawirodihardjo : Jakarta.

Purwoko, Edy. 2011. Kebijakan Penggunaan Metode Kontrasepsi Jangka Panjang (MKJP) dalam Jampersal. Forum Nasional II : 
Jaringan Kebijakan Kesehatan Indonesia. Makasar.

Sari, E. I., Nurhidayati, E., \& Isnaeni, Y. (2016). Faktor-Faktor Yang Berhubungan Dengan Rendahnya Minat Ibu Terhadap Penggunaan Metode Kontrasepsi Jangka Panjang Di BPS Sri Romdhati Semin Gunungkidul.

Shodiq, Munawar. 2016. Faktor yang Mempengaruhi Rendahnya Kesertaan KB Melalui Metode Kontrasepsi Jangka Panjang (MKJP) di Kabupaten Tulang Bawang Barat. Prosiding Pertemuan Ilmiah Ikatan Widyaiswara Indonesia : Jakarta.
Sulistyawati, Ari. 2012. Pelayanan Keluarga Berencana. Salemba Medika : Jakarta.

Sugiyono. 2009. Metode Penelitian Kuantitatif, Kualitatif, dan RED. Alfabeta: Bandung. Suryanti, Y. (2019). Fakto-Faktor Yang Berhubungan Dengan Penggunaan Metode Kontrasepsi Jangka Panjang Wanita Usia Subur. Jambura Journal of Health Sciences and Research,1(1), 2029.

Winner, Brooke dkk. 2012. Effectiveness of Long-Acting Reversible Contraception. The New England Journal of Medicine : Jakarta. 